\title{
Insights into the Skill Development Issues of Management Jobs: A Study on RMG and Textile Sectors of Bangladesh
}

\author{
Saiful Islam ${ }^{1} \&$ Tasneem Nabila Islam ${ }^{2}$ \\ ${ }^{1}$ Assistant Professor, Department of International Business, University of Dhaka, Bangladesh \\ ${ }^{2}$ Freelance Researcher, MBA, Department of International Business, University of Dhaka, Bangladesh \\ Correspondence: Saiful Islam, Assistant Professor, Department of International Business, Faculty of Business \\ Studies, University of Dhaka, Bangladesh. Tel: 88-019-1146-3733. E-mail: saifulib@du.ac.bd
}

Received: September 17, 2018

Accepted: October 19, 2018

Online Published: November 29, 2018

doi:10.5539/ass.v14n12p56

URL: https://doi.org/10.5539/ass.v14n12p56

\begin{abstract}
The purpose of this study is to provide an insight into the skill development and training related issues of the management jobs of textile and garments sector of Bangladesh which includes the skills requirements, differences in the skills of domestic managers and expatriates, local training facilities and barriers companies confront while sending their staffs abroad for training. A qualitative research approach has been adopted in this study where data has been collected through 30 in-depth interviews based on convenient and snowball sampling. The findings indicate that certain skills of domestic managers are quite poor like English proficiency, presentation skills, leadership skills, decision making skills. The RMG and textile firms send their employees to Germany, China, UK, USA, Japan and other countries for training but they encounter barriers like visa issues, breach of contract by the employees etc. in this attempt. Government, RMG and textile industries and various trade bodies, educational and training institutions should step up to organize training, develop skill-oriented curriculum to eliminate the reasons of hiring expats. The outcome of this study can be a source material through which HR managers can identify the scarce managerial skills and devise training and skill development programs accordingly not only in Bangladesh, but also in similar developing countries.
\end{abstract}

Keywords: Bangladesh, management, readymade garments, skill development, textile sector

\section{Introduction}

Ready Made Garments (RMG) and textile industries are two most significant industries that have major contribution in the economy of Bangladesh. More than $80 \%$ of foreign earnings come from the export of RMG every year. However, a lot of foreign nationals are working in this industry which results in the rise of unemployment and outflow of foreign currency reserve of this country. At the inception of this industry in 1980, the ratio of foreign nationals was comparatively higher than that of today because of limited technical hands and required educational background of local employees. Over the time such proportion has been reduced to a great extent as these industries have become self-sufficient (Rahman, 2017). Usually, foreign nationals are still needed for a few months such as trial running after importing new machinery, but after that period they are not needed at all. However, foreign nationals still hold a significant proportion in RMG and textile industry of Bangladesh which should be occupied by local employees at present.

According to the Stark, Frederick, Gereffi (2011), many of the quotas that used to regulate global apparel market previously had phased out after the formation of the Agreement on Textile and Clothing (ATC) under World Trade Organization (WTO) and this has enabled low-cost countries like China, India and Bangladesh to emerge as global leaders and compelled small countries to upgrade into branding and design which has made the development of workforce skills an imperative. However, the increasing learning gap in the industry results in higher dollar outflow which in turn results in lower foreign exchange retention and may eventually decrease competitiveness of Bangladesh in the global market.

In this regard, while the reasons behind appointing foreign nationals are explored, it is evident that many RMG owners have inbuilt mentality that anything foreign is better than the local. Except few foreign technicians who have truly vast knowledge and experience in the textile garment industries, $90 \%$ or more are having equal or lower skills compared to our textile graduates (Rahman, 2017). Islam, Hossain, Islam, Tareq (2017) 
recommended in their study that various stakeholders of apparel and textile sector should facilitate local employees with training and skill development programs, apex trade bodies like BKMEA, BGMEA should maintain database of foreign employees working in this sector and government should revise their policies and increase monitoring.

The lack of proper planning, faulty educational system, sluggish job growth, poor investment in human resource development are some of the reasons of foreign manpower occupying the mid-level jobs particularly acute in the RMG industry of Bangladesh. Thus, this study is intended to provide an insight into the skill development and training related issues of the managerial positions of various RMG and textile firms of Bangladesh. Therefore, to achieve this aim, the objectives of this study are; first, to analyze the differences between the skills of local and foreign employees for management positions, second, to provide an overview of the skills required for the management positions, third, to explore the training or skill development programs that are conducted for making the local employees capable for those management positions, fourth, to find out the barriers of sending local managers abroad for training purpose and fifth, to identify some areas of improvement to make local employees more capable.

Through this study, the scarce and critical skills of the managerial positions can be identified and factory owners, different stakeholders like government, BGMEA, BKMEA, BUETEX will feel the importance of making the local nationals competent for the managerial jobs which is currently being occupied by expatriates mostly and undertake steps to alleviate the reasons of hiring foreigners in those positions. The outcome of the study will be a source material for HR managers or factory owners, trainers or teachers of different vocational and training institutes or different universities of textile and garments sector to focus on the scarce managerial skills and will be able to devise their training and skill development programs accordingly.

In this regard, the organization of the study has been discussed as follows. The next section reviews different studies and literatures so far have been conducted on the issues related to this study in order to identify the areas of further research. Chapter three discusses the methodology i.e., the justifications behind categorizing the research as exploratory and the reasons behind adopting snow ball sampling method, in-depth interviews as opposed to survey. Chapter 4 talks about the findings and discussion of this study and finally, in the last section, the study has been concluded with determining key areas of improvement.

\section{Literature Review}

The existence of expatriates in different industries of Bangladesh has become a pressing issue now-a-days as they are occupying the jobs that could otherwise be retained by the local graduates. One of the most important factors behind this trend is skill gap. Skill gap exists when employers find it difficult to recruit personnel because the available candidates lack the skills needed to carry out the roles of business and therefore a learning culture should be promoted which is essential for this industry especially for transferable skills (Pye, 2002). According to this study, in the clothing industry managers, IT specialists, designers, engineering technicians, garment technologists are some of the posts in which the skill needs are expected to rise. Foreign language, team working, problem solving, managerial, adaptability, time management, customer handling is the future skill needs of apparel industry and the skill gaps is anticipated to be the highest in the managerial occupations of this industry.

To fill up this skill gap with foreign nationals, Syed, Hazboun and Murray (2013) in their study indicated that local staffs have no issues on working with the proficient expatriates if they add value to the organization and thus expatriation may be welcomed in order to boost the performance of the business if a particular expertise is absent in the host country. However, Toh and DeNisi (2005) revealed that local employees perceive differences while they find differential treatment between local staffs and expatriates which begins with the unequal remuneration packages. As a suggestion to overcome such perception, firms should change their compensation policy, use transparent procedures to pay and promote, train and groom local staffs in much the same way the expatriates are groomed and most importantly they should use and reward local mentors.

Expatriates are generally recruited in the senior and mid-level managerial posts. A research commissioned by Department of Labor, South Africa revealed some of the areas like senior managers, professionals, artisans, technicians and others where scarce skills exist and identified some critical skills of clothing and textile industry such as HR management skill, communication, marketing or sales, cost analysis, financial management, personal development, technical training skills which are fundamental for managerial jobs in this sector (Morris \& Reed, 2008). Manpower Group (2011) survey revealed that skill shortage is acute at the management level in Vietnam and this survey also labeled grasp of legal and financial basics, sense of responsibility to manage and delegate resources, motivational, communication, foreign language and some other skills as generic skill deficits among middle managers. 
However, lack of funding, high cost of training, government red tape, unwillingness of employees, high employee turnover is some of the barriers to reduce the skill gaps in apparel industry (Pye, 2002). Furthermore, Morris and Reed (2008) also pinpointed lack of training, absence of suitable courses, unwillingness of staffs as obstructions to maintaining a talented workforce. Educators said that they do not have the information that is required to devise better curricula to make the graduates employable indicating the fact that the young folks are not being prepared with the necessary skills and this is a critical hindrance to the growth of developed and particularly for developing countries which induced employers to seek labor from abroad (Aring, 2012).

Although Bangladesh employed expats in 1980s which complemented the jobs since there was a scarcity of local graduates with technical expertise, the employment of foreigners now has turned into substitution as locals have developed their skills in this sector. Besides, there exists a wrong perception among Bangladeshi people that women are less competent for the managerial posts. Thus, it can be said that there exist gender undercurrents along with skills and learning gap for the managerial positions of the RMG of Bangladesh and for efficiency gain, the development of managerial skills is a requisite (Macchiavello, Menzel, \& Woodruff, 2014).

Expatriates have some specialized skills that make them superior to local managers. In this regard, a study conducted by Islam, Hossain, Islam and Tareq (2017) on the RMG sector for Centre of Excellence for Bangladesh Apparel Industry (CEBAI) where they have pointed out that expats have specialized skills in communication, negotiation, leadership, decision-making and operational skills and were found to be paid two to five times higher than that of the local staffs. The absence of managerial training in TVET institutions is seen as one of the reasons which results in the dearth of efficient human capital for the managerial positions of this sector (Islam, 2014).

Moreover, unavailability of skilled middle management is a crucial aspect for which the improvement of productivity of Bangladesh RMG sector is being restricted and the non-existence of educational institutions, the unattractive nature of this industry among the local graduates have been cited as major causes behind it (Berg, Hedrich, Kempf \& Tochtermann, 2011). However, Hossain, Sarker and Afroze (2012) conducted a study on 52 mid-level managers of Urmi Group to assess seven managerial skills including goal setting ability, strategic strength, decision-making, delegation skills, conflict management skills, authority role model, leadership skills, and networking skills. This study of management development training program uncovered that managers of RMG sector lack positive goal setting behavior, positive delegation, lack of understanding of the significance of the networking and building relationships and recommended that substantial training is required to improve strategy formulation and goal setting capabilities.

On the other hand, Fernandez-Stark, Frederick and Gereffi (2011) found that 3-4\% of the workers are involved in positions like engineers, mechanical technicians, production planners, operations support and in order to support new functions like design, finance, logistics and marketing, employees with advanced skills are required. Besides, the management style of RMG sectors of this country is more reactive than proactive and they lack both the skills and determination to overcome their inefficiencies. To address the issue of the shortage of adequate managerial skills, initiatives are required from both public sector and private sector although skill training programs for mid-level management and fashion designing exist in certain institutions such as BGMEA, BUFT (Hossain, 2017).

Thus, based on the literatures and previous studies it is assumed that there is hardly any academic research focusing on the skills and training of domestic and foreign managers working in textile and RMG sector of Bangladesh. Moreover, those studies did not address the issues associated with sending local employees abroad for training purpose and countries in which local employees are sent for training, costs of training by a foreigner and so on. Thus, there is ample scope to initiate some explorative research on skill development and training related issues like research on skills differentials between local and foreign employees, level of skills scarcity, and scope for training and capacity building of RMG and textile industry of Bangladesh which can be fulfilled by research on the related issues.

\section{Methodology}

\subsection{Research Approach}

In order to dive deeper into the skill development and training related issues of textile and RMG industry of Bangladesh, the current study adopts a qualitative research technique. This exploratory research in its kind has been conducted by collecting primary data in a non-randomized and flexible fashion and those data is being used to understand the current situation of selected areas. Moreover, the findings of this study can be used in further studies especially in conclusive research with more advance statistical analysis. 


\subsection{Population and Sample}

There are 4482 garment factories that hold membership in the year 2016-17 under BGMEA, according to the trade information of BGMEA (2018) and there are 1461-member mills under BTMA among which 425 are Yarn manufacturing mills, 796 are Fabric manufacturing mills and 240 are Dyeing-Printing-Finishing mills (BTMA, 2017). However, no specific information is available regarding either the total number of expats working in the textile and RMG industry of Bangladesh or the total number of expats in each level of management. Thus, this study adopts a non-random sampling method since it was impossible to determine an appropriate sample frame for probability sampling. As it is an exploratory research, the approach matches with the nature of the study.

To develop the sample of this study, snowball and convenience sampling techniques are used. The reasons behind using these sampling techniques are that they can be carried out conveniently within short span of time and by asking questions to a handful of easily approachable people. As there is no specific information regarding expats employed in various firms within the industry, taking referrals from the initial respondents was also important. However, the firms that denied that they do not have any foreign employee have not been considered in the sample. Therefore, sequentially ten such RMG and textile firms which disclosed they employ foreign employees in their companies have been included in the sample and have been selected to take interviews. Interviews have been taken from at least one personnel from three levels of management- top management/owners, middle management and line management in order to collect information regarding the skills and training related issues of domestic and foreign managers. In total, thirty experts from the industry are interviewed in the study.

\subsection{Data and Sources}

To accomplish the objectives of this study specific list of questions has been developed for interviews regarding the skills and training related issues of textile and garments sectors of Bangladesh. Specific data has been collected through interviews are what their specialized skills are, whether they provide any training or take foreign technical assistance, which skills are absent among local staffs compared to that of the foreign employees and to provide the perception of different stakeholders regarding how to make local employees capable, specific questions have been asked and interviews have been taken with pre-prepared interviews. Moreover, articles, journals, organizational report, online publications, textile and RMG related magazines and business publications like Textile Today, Textile Focus, and newspaper have been used to collect raw data. Because of their ease of accessibility, low cost of obtaining data and because of time limitations, these sources have been used.

\subsection{Data Collection Method}

Data has been collected through in-depth interviews of target respondents by paying visit to the workplaces included in the sample. Since pre-determined questions have been asked along with some additional questions to clarify particular issues, the interviews are categorized as semi-structured. With the permission of the interviewees, the interviews were digitally recorded and written down. However, the interviewees inhibited to disclose both the name of the companies and the name of the participants. The interviews are conducted at a time convenient for both the participant and the researcher and lasted for around 1 or 1.5 hours. The total data collection process took four months from February 2018 to May 2018. While other relevant information has been collected from published journals, magazines, newspapers and websites as they seems fit, dichotomous, two alternative questions are included in the interview questions. Moreover, in order to evaluate the perception of respondents regarding the skills of local graduates compared to expatriates within a given range of values, scaling questions have been used.

\subsection{Data Analysis Techniques}

A widely used qualitative data analysis technique, content analysis has been used in this study to analyze the data. This research method involves subjective explanation of the content of the data through logical identification and categorization of different patterns or themes of data. In this study, the data have been grouped into different categories namely skill overview of management positions of garments and textile sector, skills of local staffs compared to expatriates, training and skill development programs to make local staffs more capable and a provision of the areas of improvement. Moreover, data have also been analyzed in descriptive nature using simple tables and logical explanation.

\section{Findings and Analysis}

The enormous skill gap at mid and higher-level management posts made it credible for 200,000 foreigners working in this country mostly in RMG and textile sector in supervisory and managerial positions (High Time to think, 2017). Mostly South Asian and Asia Pacific nationals like Singapore, Taiwan, Vietnam, India and Pakistan, 
Sri Lanka are preferred and recruited in big portfolio and technical positions (Patwary, 2015). Mirdha (2015) mentioned in a study that majority of the foreign nationals are employed in top posts like production managers, merchandisers, senior sewing operators, cutting masters, designers and washing experts in the garments sector.

\subsection{Local Staffs' Skills Compared to Expatriates}

Domestic managers lag behind the expatriates in case of several skills. The following table (table 1) represents the degree of agreement of different industry experts interviewed regarding the skills of local employees compared to that of the foreign employees. Among the above-mentioned set of skills, none of experts of this industry have agreed that local employees have a higher position compared to that of foreign employees. However, based on the average scores come from the experts interviewed, the local employees have a medium or average position compare to foreign employees on communication skill, motivational skill, managerial skill, accounting skill, networking skill, negotiation skill, and IT skill. On the other hand, according to the experts, local employees are lag behind the foreign employees on some important skills like, English proficiency skill, presentation skill, leadership skill and decision-making skill which in turn make the foreign employees more competent and opens a better employment opportunity for them in textile and garments industry of Bangladesh.

Table 1. Five Industry Experts' Degree of Agreement with the Skill Sets of Local Employees Compared to that of the Foreign Employees

\begin{tabular}{|c|c|c|c|}
\hline Skills of Local Employees & Low (1) & Medium (2) & High (3) \\
\hline Communication skill & & 2 & \\
\hline English Proficiency & 1 & & \\
\hline Presentation Skill & 1 & & \\
\hline Motivational Skill & & 2 & \\
\hline Leadership Skill & 1 & & \\
\hline Managerial Skill & & 2 & \\
\hline Decision-making Skill & 1 & & \\
\hline Accounting Skill & & 2 & \\
\hline Networking Skill & & 2 & \\
\hline Negotiation Skill & & 2 & \\
\hline IT Skill & & 2 & \\
\hline
\end{tabular}

Source: Author Constructed

\subsection{Overview of Skills of Management Positions}

This section focuses on different skills required at various top and mid-level management jobs of textile and garments sector, the scarce skills in the local job market and the specialized skills of different countries in this sector.

\subsubsection{Scarce Skills}

In his study, Patwary (2015) revealed that the skills required local employees in operation, functional, management and strategic level in the RMG sector of Bangladesh do not match and fit because of the conventional higher and post-secondary education system in this country and makes sourcing from home inadequate. The skill level of mid and higher-level managers and supervisors in Bangladesh has not attained the required standard and they lack adequate professional skills including merchandising, communication with business world, planning \& designing of the production processes, business ethos, leadership, motivational skills etc. (High Time to think, 2017). In addition to these, an in-depth interview with different people involved in RMG and textile businesses indicated some of the areas where local employees are not competent. These areas include Printing, Merchandising, Fashion Designing, Technological skills, Supply Chain, Software Expertise, Industrial Production Engineering, and Higher Value-added Products.

\subsubsection{Skills of Expatriates}

Expatriates are equipped with both soft and hard skills as demonstrated in the above table (table 2). Although Bangladeshi employees have the top and mid-level skills, they are not good at soft skills like communication, leadership, negotiation and presentation. All these skills are pre-requisite for occupying management posts in RMG sector (Islam et al., 2017). 
Table 2. Occupation, positions, and key skills of expatriate employees

\begin{tabular}{|c|c|c|c|c|c|c|c|c|c|c|c|}
\hline Name of Occupations & 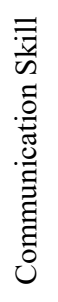 & 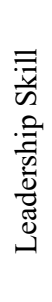 & 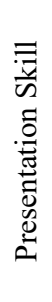 & 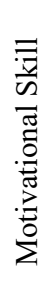 & 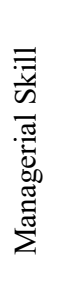 & 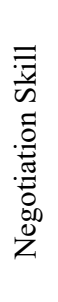 & 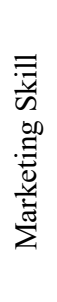 & 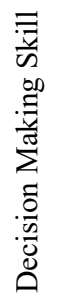 & 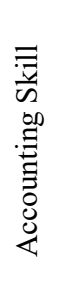 & 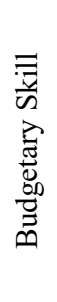 & 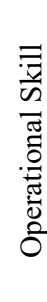 \\
\hline $\begin{array}{l}\text { Country Manager/ Regional Head/ Chief Advisor/ Managing } \\
\text { Director/ Chief Executive Officer/ Chief Operation Officer/ } \\
\text { Additional Managing Director }\end{array}$ & $\checkmark$ & $\checkmark$ & $\checkmark$ & $\checkmark$ & $\checkmark$ & $\checkmark$ & $\checkmark$ & $\checkmark$ & & & \\
\hline Chief Finance Officer & & & $\checkmark$ & & & & & & $\checkmark$ & $\checkmark$ & \\
\hline General Manager/ Deputy General Manager/ Deputy Director & $\checkmark$ & $\checkmark$ & $\checkmark$ & $\checkmark$ & $\checkmark$ & & & & & & $\checkmark$ \\
\hline Assistant General Manager & $\checkmark$ & $\checkmark$ & $\checkmark$ & $\checkmark$ & $\checkmark$ & & $\checkmark$ & & & & $\checkmark$ \\
\hline Senior Manager/ Manager/ Deputy Manager & $\checkmark$ & & & $\checkmark$ & $\checkmark$ & & & & & & $\checkmark$ \\
\hline $\begin{array}{l}\text { Head of Technical Department (Dyeing, Washing, Cutting, } \\
\text { Printing, Finishing) }\end{array}$ & $\checkmark$ & & & $\checkmark$ & $\checkmark$ & & & & & & $\checkmark$ \\
\hline $\begin{array}{l}\text { Head of Non-Technical Department (HR, Admin, Compliance, } \\
\text { Accounts, Audit) }\end{array}$ & $\checkmark$ & & & & $\checkmark$ & & & & & & \\
\hline $\begin{array}{l}\text { Quality Assurance Manage/ Technical Director/ Vendor Key } \\
\text { Responsible (VKR) }\end{array}$ & $\checkmark$ & & & & $\checkmark$ & & & & & & $\checkmark$ \\
\hline
\end{tabular}

Source: Islam et al. (2017)

4.2.3 Skills Required for Different Managerial Posts

In addition to overall skills with which expatriates are equipped, the Table 3 provides an overview of different skills, knowledge and experience required to work in textile and garments sector.

Table 3. Skills and Knowledge Requirements of Different Managerial Posts

\begin{tabular}{ll}
\hline Posts/ occupations (Top and Mid-level) & Skills/Knowledge/Experience Required \\
\hline Chief Executive Officer (CEO) & Ability to coordinate overall business activities of the entire organization \\
Chief Marketing Officer (CMO) & Ability to carry out overall marketing and merchandising activities \\
General Manager (GM, Operations) & Have to be specialized in the operational activities of relevant industry \\
General Manager (GM, Marketing) & $\begin{array}{l}\text { Should have vast knowledge and experience in international apparel } \\
\text { marketing }\end{array}$ \\
General Manager (GM, HR and Admin) & Vast knowledge and experience required on modern Human Resource and \\
Leneral Manager (GM, Merchandiser) & Required to have knowledge and experience in supply chain and costing \\
General Manager (GM, Production) & Should have practical experience in apparel production and techniques \\
General Manager (GM, Accounts) & Vast experience in audit and accounts \\
Compliance Manager & Specialization in compliance issues and labor activities \\
Manager Audit & Qualification from ICMA, CA, ICSB and should have practical experience \\
in audit conduction
\end{tabular}

Source: Author Constructed

\subsubsection{Specialization of Different Countries}

Different countries specialize in different areas of RMG and textile sector which are considered while expats are appointed in Bangladesh. From the data of in-depth interviews with different industry experts, this next table has been generated. 
Table 4. Specialization of Different Countries in Textile and RMG Industry of Bangladesh

\begin{tabular}{ll}
\hline Name of the Country & Specialization \\
\hline India & Dyeing, International Marketing, Merchandising \\
Sri Lanka & Research and Development, Oven garments, Merchandising \\
Thailand & Printing \\
Turkey & Dyes and Chemical Usage \\
Pakistan & Dyeing, Woven Garments, Yarn, Technology \\
China & Machineries, Dyeing and Chemical Usage, Yarn, Cotton, Accessories \\
Philippine & Oven Garments \\
Italy & Machineries and Equipment \\
Korea & Yarn \\
German & Machineries \\
Australia & Cotton, Spinning Mill \\
Europe & Machineries, Dyes and Chemicals, Accessories \\
Japan & Machineries, Dyes and Chemicals \\
Indonesia & Yarn \\
Uzbekistan & Cotton, Spinning Mill \\
Vietnam & Yarn \\
\hline
\end{tabular}

Source: Author Constructed

\subsection{Training and Skill Development Programs Conducted for Making Local Employees Capable of Managerial Positions}

Grooming a strong mid-level management for handling such a large sector is another big challenge for the near future. Making the local staffs capable for doing the tasks of foreign employees will build up the confidence of the management, save foreign nationals and increase efficiency ("Groom 'local talent for mid-management positions", 2017). In Bangladesh there are three specialized Private and Public Universities and two Engineering Colleges dedicated to Textile Engineering Education. Many Private Universities now also have School of Textile engineering operational to meet the demand of this sector at mid and entry level management (Patwary, 2015). In this connection, following are the few training, skill development and initiatives that have already been taken by different stakeholders and organizations.

\subsubsection{Initiatives by the Government}

Government has taken an initiative to train up young generation to brush up their skills and make them capable of being employed which has been named as "Youth Development Program". The project is executed by the department of youth. Besides this, the government runs several projects with ILO and UNDP. Besides, government planned to set up two dozen of textile engineering colleges and vocational institutes. If this becomes operational, then the requisite number of textile engineers and technologists will be produced (Hashim, 2015).

\subsubsection{Countries Preferred for Foreign Technical Assistance}

Domestic employees are sent abroad for training for several purposes especially when a new machine is installed. These trainings last for two or three weeks and at times for around two-three months. The expenses are sometimes assumed by the exporters and sometimes by the companies. The countries to which the interviewed firms send their employees for training on different issues like new machinery, technology is given below in the table (Table 5). Besides, employees are also sent to other countries like France, India, and Korea and so on.

Table 5. The Countries to which Firms Send Employees for Training Purpose

\begin{tabular}{ll}
\hline Name of the Countries & Training Content \\
\hline German & Dyes and Chemical Usage, Marketing \\
Thailand & Dyes and Chemical Usage \\
China & Machinery installation and maintenance, Fabric \\
Japan & Development of Human Resource \\
Italy & Technology and Machine \\
Turkey & Technology \\
United Kingdom & Marketing \\
America & Cotton \\
\hline
\end{tabular}

Source: Author Constructed 


\subsubsection{SEIP Project of Finance Division under Ministry of Finance}

In an effort to establish 'Executive Development Centers' (EDC) at the universities to carry out a nine-month training program to create and build up world class mid and higher level managers, the SEIP Project of Finance Division under Ministry of Finance will work with the industrialists and leading universities of the country. This program aims to train 2,250 trainees for a period of 3 years during the second phase of SEIP which has started in 2017. The project will continue up to 2024 and in successive stages with different selected universities if its outcome and demand permits so (High Time to think, 2017).

\subsubsection{BGMEA, BKMEA and BUFT}

BGMEA, BKMEA have established several training institutions to develop skills of personnel working in this sector namely National Institute of Textile Engineering and Research (NITER) at Savar and BGMEA University of Fashion and Technology. Moreover, 'BGMEA University of Fashion \& Technology' that provide education, training, research and development aimed at producing highly dynamic, knowledgeable, qualified and skilled human resources in particular for mid-level executives including international standard designer, merchandiser, production manager and quality inspector in the functional level (Patwary, 2015).

4.3.5 Training Organized by CEBAI and role of Bangladesh Institute of Management (BIM)

The 'first Capacity Development Program for Mid-level Managers of RMG Industries' was organized by the Centre of Excellence for Bangladesh Apparel Industry (CEBAI) in collaboration with Buildtek Consultants of Sri Lank in which a total of 52 participants received certificates at the end of the training. CEBAI will continue this training program with its own trainers in the future for developing the mid-level managers of RMG sector ("Groom 'local talent for mid-management positions", 2017). To improve the technical skills of middle level management, Bangladesh Institute of Management provides training on lean manufacturing, productivity and quality management in addition to its core focus of courses related to marketing and human resource management.

\subsubsection{Trainings Conducted by Different Companies}

This study reveals that, different companies organize training programs on different issues for the local employees. Usually the training costs from tk. 50,000 to tk. 250,000 and even it can cost tk. 500,000 depending on the duration and contents of training and can last for two-three weeks or three-five months. Companies provide training to the local staffs on the issues, like, Quality, Standard Minute Value (SMV), Compliance, and Merchandising.

\subsection{Barriers to Sending Local Employees Abroad for Training}

Certain issues are associated with sending local employees abroad for training or bringing foreign trainers to brush up the skills of domestic employees. These barriers discourage employers to send their employees overseas for training. Among many barriers and challenges few are like, there is a possibility of breach of contract once a potential trained employee switch to a better job with higher remuneration after getting the international training arranged and funded by parent company. Therefore, companies are not interested to arrange international training for its current employees as such training are significantly costlier than arranging one in domestic institutions. Even if firm arranges such, there is always a fear among the employers that if the local staffs are sent abroad for training purpose, they may never come back. In addition to these, in case of international training, both employers and local employees face various problems regarding visa, matching training schedules and cultural shock and adjustment.

\section{Conclusion}

Because of shortage of appropriate skills and expertise in the home country, a lot of expatriates are recruited in the textile and garments sectors of Bangladesh. Although different textile universities and training institutes have been established to enhance the skills of domestic managers, they still lack in some specific skills like presentation skills, decision-making skills, leadership skills, English proficiency and so on. Moreover, the findings of current study suggest that expatriates are superior to domestic managers in terms of managerial, motivational, negotiation, communication, marketing, decision making skills and few others.

In addition to these, according to the interviewed experts of RMG and textile sectors of Bangladesh, printing, merchandising, fashion designing, technological skills, supply Chain, software expertise, industrial production engineering are the scarce skills. If the trend of hiring foreign employees increases, the unemployment situation will become more acute for the local graduates. Different stakeholders like government, BGMEA, BKMEA, BUTEX, CEBAI, BUFT, ILO run a number of programs in order to build up the skills of personnel working in 
this sector. However, such programs and initiatives still fall inadequate to meet the required number of skilled manpower for the industry.

Besides, companies take foreign technical assistance from expats of different countries like German, Thailand, China, Japan, Italy, and United Kingdom to meet companies' required technical know-how in production and export. In some instances, such technical assistance from foreign employees also helps local employees to develop skills in themselves. However, best approach of learning such skills would be acquiring same from source rather than from expats of these countries. However, current study finds that arranging training for local staffs in foreign countries is limited for various barriers. The impediments to training up local staffs abroad that include breach of contract, visa issues, likelihood of not returning to the home country etc.

To address these issues, all the stakeholders of this industry should step up necessary measures to ensure appointment of local employees instead of expats in the management positions. Different stakeholders like employer, employee, government, trade bodies, engineering and training institutes along with other organization such as BIDA, BMET should step up measures to reduce reliance on foreign employees and make local graduates more capable to work in the management posts of RMG and textile sector. These stakeholders can perform various roles to lessen dependency on expatriates. The expected roles from these stakeholders are mentioned briefly in the following. First of all, owners or employers should identify the scarce skills and provide training to the domestic managers even by bringing trainers from abroad instead of hiring expatriates. Secondly, local graduates should gain professional skills through participating in different skill-oriented training and be familiar with global business and fashion trend. Thirdly, government should provide training to local graduates by foreign experts on technology as a part of their "Youth Development" Program, and organize different trainings for free of cost and establish more training institutes.

In addition to government efforts, institutions like BGMEA, BKMEA, BUFT, BUTEX and other institutions may also play a significant role in this regard. BGMEA and BKMEA may facilitate in sending local managers abroad for training purpose, assist in obtaining visa for local staffs and organize different training programs home and abroad. BUTEX and other academic institutions may take a leading role on organization of professional development programs, arrange internship for students and outline skill-oriented curriculum. Last but not the least, BUFT may introduce and coordinate more professional courses on fashion designing in collaboration with foreign fashion colleges.

Moreover, the following points might be taken into account in order to enhance the required skills of local graduates for the RMG and textile sectors. First of all, the educational and training institutes, universities that run textile and garments related courses should focus on providing training on technical issues, latest technologies, global marketing, product presentation, new fashion trends etc. Second, coordination among different stakeholders of this industry must be ensured to run skill development programs and invest in enhancing the skills of home country human capital. Third, more fashion designing studios and color labs should be established. Fourth, local graduates should be provided with proper training so that they can build up skills for working in this sector. Fifth, companies should in collaboration with British council, AKS Khan Centre for Excellence, Democracy watch or similar institutions to organize training to enhance English proficiency of local managers and last but not the least, BMET should step up to provide vocational and technical training as well as initiate formal, informal, special training courses particularly for the local graduates who want to pursue career as a manager of RMG and textile industries.

More than eighty percent of export earnings of Bangladesh come from RMG and textile industry currently. However, a large proportion of middle and top management positions are detained by foreign expats. To provide an insight into the skill required, development of local employees and training related issues of the managerial positions of various RMG and textile firms of Bangladesh, this study is initiated. This study does not attempt to recommend generalizing the skills requirement and development identified rather provides information that can be useful to improve the current situation of dependency on expats rather than developing local manpower. Moreover, this study accumulates information regarding current scarcity and position of skills required RMG and textile industry in Bangladesh. Thus, this study would be valuable in understanding current situation and gap of skilled workforce and management in RMG and textile industry of Bangladesh.

Such an exploratory study, therefore, open the scope for further research in this regard. Based on the current gap and situation of skills required in RMG and textile industry of Bangladesh identified in this study, further research could be initiated to design policy measures to fill up these needs and gaps. Further studies should include more experts of this field as respondents to develop more conclusive findings. To overcome the limitation of the current study, like time constraint, limited quantitative analysis and inadequate respondent size, 
future studies should be in more details and address broader aspects and more specific areas within skills development program of RMG and textile industry of Bangladesh.

\section{References}

Aring, M. (2012). Youth and Skills: Putting Education to Work. Report on Skills Gaps. UNESCO. Retrieved from http://unesdoc.unesco.org/images/0021/002178/217874e.pdf

Berg, A., Hedrich, S., Kempf, H., \& Tochtermann, T. (2011). Bangladesh's ready-made garments landscape: The challenge of growth. Apparel, Fashion \& Luxury Practice. Retrieved from https://www.mckinsey.de/files/2011_McKinsey_Bangladesh.pdf

BGMEA. (2018). Trade Information: Membership and Employment. Retrieved from http://www.bgmea.com.bd/home/pages/tradeinformation

BTMA. (2017). Basic Data of Primary Textile Sector. Retrieved from https://www.btmadhaka.com/downloads/basic-data-of-btma-december-2017.pdf

Fernandez-Stark, K., Frederick, S., \& Gereffi, G. (2011). The Apparel Global Value Chain: Economic Upgrading and Workforce Development. CGGC Research Projects. Retrieved from http://www.cggc.duke.edu/pdfs/2011-11-11_CGGC_Apparel-Global-Value-Chain.pdf

Groom 'local talent for mid-management positions in RMG industry. (2017). Financial Express. Retrieved from https://thefinancialexpress.com.bd/trade/groom-local-talent-for-mid-management-positions-in-rmg-industry $-1512365934$

Hashim, S. M. (2015). Skilled manpower shortage. Daily Star. Retrieved from http://www.thedailystar.net/op-ed/politics/skilled-manpower-shortage-166294

High Time to think about Special Economic zone and BCS Cadre for textile engineers. (2017). Textile Focus. Retrieved from http://textilefocus.com/high-time-think-economic-zone-bcs-cadre-textile-engineers/

Hossain, A. (2017). Can Managers Be Trusted? Looking at the Bangladesh Ready Made Garments Industry.

Hossain, C. G., Sarker, M. A. R., \& Afroze, R. (2012). An Assessment of Managerial Skills in the Labour Intensive Industry: A Case Study of a Garments Manufacturing Firm. Journal of Accounting, Business \& Management, 19(2), 1-14. Retrieved from http://search.ebscohost.com/login.aspx?direct=true\&db=bth\& $\mathrm{AN}=82028806 \&$ site $=$ ehost-live

Islam, M. N. (2014). Mid-level Management Skills in RMG sector. Retrieved from http://www.bmet.gov.bd/BMET/resources/Static PDF and DOC/publication/Brief on Mid-level management skills in RMG sector.pdf

Islam, S. R., Hossain, M. I., Islam, M. T., \& Tareq, M. (2017). Employment of Expatriates and its Alternatives in the RMG sector of Bangladesh. Report of Centre of Excellence for Bangladesh Apparel Industry. Retrieved from https://cebai.org/wp-content/uploads/2018/01/Research-Report-on-Employment-of-Expatriates-and-its -Alternatives-in-the-RMG-Sector-of-Bangladesh.pdf

Macchiavello, R., Menzel, A., \& Woodruff, C. (2014). Managerial Capital and Productivity: Evidence from a Training Program in the Bangladeshi Garment Sector. Retrieved from https://economics.nd.edu/assets/147311/paperfemale_impact_141007cw.pdf

Manpower Group. (2011). Building a High-Skilled Economy: The New Vietnam. Retrieved from http://files.shareholder.com/downloads/MAN/1632021502x0x517559/07ff846a-0f19-4709-bf98-b1dfb048f 3e3/Building_A_High-Skilled_Economy_

Mirdha, R. U. (2015). Foreign employees on the rise in Bangladesh. Daily Star. Retrieved from $\mathrm{http} / / / \mathrm{www}$.thedailystar.net/business/foreign-employees-the-rise-bangladesh-194584

Morris, M., \& Reed, L. (2008). A Sectoral Analysis of Skills Gaps and Shortages in the Clothing and Textile Industry in South Africa. Report for the Human Sciences Research Council. Retrieved from http://www. labour.gov.za/DOL/downloads/documents/research-documents/Clothingandtextileindustry_DoL_Report.pdf

Patwary, A. A. (2015). Skill gap in Textile \& RMG Industry and vision 2021. Textile Today. Retrieved from https://www.textiletoday.com.bd/skill-gap-in-textile-rmg-industry-and-vision-2021/

Pye, M. (2002). An assessment of skills needs in the clothing, textiles, footwear and leather and furniture, furnishings and interiors industries. Retrieved from https://core.ac.uk/download/pdf/4154530.pdf

Rahman, M. J. (2017). Aspects of foreign employees in Bangladesh textile and RMG industry. Textile Today. 
Retrieved

from

https:/www.textiletoday.com.bd/aspects-foreign-employees-bangladesh-textile-rmg-industry/

Syed, J., Hazboun, N. G., \& Murray, P. A. (2013). What locals want: Jordanian employees' views on expatriate managers. The International Journal of Human Resource Management, 25(2), $212-233$. https://doi.org/10.1080/09585192.2013.812975

Toh, S., \& DeNisi, A. (2005). A local perspective to expatriate success. Academy of Management Executive, 19(1), 132-146. https://doi.org/10.5465/ame.2005.15841966

\section{Copyrights}

Copyright for this article is retained by the author(s), with first publication rights granted to the journal.

This is an open-access article distributed under the terms and conditions of the Creative Commons Attribution license (http://creativecommons.org/licenses/by/4.0/). 